\title{
The percentage of living bacterial cells related to organic carbon release from senescent oceanic phytoplankton
}

\author{
S. Lasternas ${ }^{1}$ and S. Agusti ${ }^{1,2}$ \\ ${ }^{1}$ Global Change Research Department, IMEDEA (CSIC-UIB), Miquel Marqués 21, 07190 Esporles, Spain \\ ${ }^{2}$ The UWA Oceans Institute and School of Plant Biology, The University of Western Australia, 35 Stirling Highway, \\ 6009 Crawley, Australia
}

Correspondence to: S. Lasternas (sebastien@imedea.uib-csic.es)

Received: 14 October 2013 - Published in Biogeosciences Discuss.: 30 October 2013

Revised: 29 September 2014 - Accepted: 11 October 2014 - Published: 26 November 2014

\begin{abstract}
Bacteria recycle vast amounts of organic carbon, playing key biogeochemical and ecological roles in the ocean. Bacterioplankton dynamics are expected to be dependent on phytoplankton primary production, but there is a high diversity of processes (e.g., sloppy feeding, cell exudation, viral lysis) involved in the transfer of primary production to dissolved organic carbon available to bacteria. Here, we show the percentage of living heterotrophic bacterioplankton in the subtropical NE Atlantic Ocean in relation to phytoplankton extracellular carbon release (PER). PER represents the fraction of primary production released as dissolved organic carbon. PER variability was explained by phytoplankton cell death, with communities experiencing higher phytoplankton cell mortality showing a larger proportion of phytoplankton extracellular carbon release. Both PER and the percentage of dead phytoplankton cells increased from eutrophic to oligotrophic waters, while abundance of heterotrophic bacteria was highest in the intermediate waters. The percentage of living heterotrophic bacterial cells (range: 60-95\%) increased with increasing phytoplankton extracellular carbon release from productive to oligotrophic waters in the subtropical NE Atlantic. The lower PERs, observed at the upwelling waters, have resulted in a decrease in the flux of phytoplankton dissolved organic carbon (DOC) per bacterial cell. The results highlight phytoplankton cell death as a process influencing the flow of dissolved photosynthetic carbon in this region of the subtropical NE Atlantic Ocean, and suggest a close coupling between the fraction of primary production released and heterotrophic bacterial cell survival.
\end{abstract}

\section{Introduction}

Heterotrophic bacteria play a key ecological role in the cycle of carbon and nutrients in aquatic systems (Cole et al., 1988; Fuhrman, 1992; Ducklow, 2000), being the major consumers of dissolved organic matter in the ocean (Sherr and Sherr, 1994; Azam, 1998). Heterotrophic bacteria recycle organic carbon through respiratory processes and channel significant amounts of dissolved organic carbon to higher levels of the pelagic food webs via the microbial loop (Williams, 1981; Azam et al., 1983; Sherr and Sherr, 1988). The availability of dissolved organic carbon (DOC) is a major constraint for heterotrophic bacterial dynamics, influencing a range of processes, including heterotrophic bacteria growth efficiency, respiration or cell activity (Kirchman et al., 1991, 2004; Carlson and Ducklow, 1996; Herndl et al., 1997; Kirchman, 1997). Indeed, a high percentage of bacterial cells are either metabolically inactive or dead in natural marine plankton communities (Choi et al., 1996; Smith and del Giorgio, 2003).

Phytoplankton, in turn, provide the main source of DOC to support bacterial dynamics (such as growth and production), linking phytoplankton and bacterial dynamics in the ocean. Phytoplankton release DOC as a result of cell lysis or direct exudation (Nagata, 2000), and about $50 \%$ of daily primary production can be released by phytoplankton as DOC (Karl et al., 1998), potentially supplying a source of carbon to heterotrophic bacteria. Extracellular release or dissolved organic carbon production by phytoplankton (DOCp) is a process mostly dependent on the phytoplankton physiological state (Fogg, 1977; Sharp, 1977; Becker et al., 2014), which 
is mediated by nutrient availability (Myklestad, 1977; Obernosterer and Herndl, 1995), incident ultraviolet (UV) radiation and photosynthetically active radiation (PAR) (Berges and Falkowski, 1998; Llabrés and Agustí, 2006), and viral infection (Mühling et al., 2005). Phytoplankton cell death results in cell lysis (Brussaard et al., 1995; Agustí et al., 1998; Agustí and Duarte, 2000) and would lead to the release of incorporated carbon compounds. Veldhuis et al. (2001) reported that senescent or dying cells, meaning those with a reduced viability (increased membrane permeability), still photosynthesized, although photosynthetic activity dropped by as much as $60 \%$ relative to that of the viable cells. Recent studies, exploring the release of DOC by phytoplankton (Agustí and Duarte, 2013; Lasternas et al., 2013), provided evidence that increasing phytoplankton mortality in oligotrophic waters led to increasing DOCp among senescent or dying natural populations and thus accounts for a large fraction of the photosynthetic carbon channeled through bacteria characteristic of oligotrophic marine communities. In a comparison of contrasting oceanic systems, Agustí and Duarte (2013) found that the percentage of phytoplankton extracellular carbon release (PER) was related to phytoplankton lysis rates, with the largest PER observed at the oligotrophic waters. Lasternas et al. (2013) found that oligotrophication, forced by an anticyclonic eddies formation in the eastern North Atlantic, resulted in increased phytoplankton cell mortality and increased PER within anticyclonic eddies' waters.

Yet, the possible relationship between the phytoplankton cell status and DOCp, on the one hand, and the status of heterotrophic bacterial cells, on the other, remains unclear. The status of bacterial cells depends on a large number of processes but is ultimately dependent on the functioning of membrane proton pumps and the integrity of the cell membrane that indeed defines the viability of bacteria (Shapiro, 2008). While there is still controversy about the differences between active and viable bacteria, the analysis of bacterial cell-membrane integrity allows the discrimination between living and dying cells and has been introduced in recent studies assessing the environmental factors driving bacterial survival (Alonso-Sáez et al., 2007; Gasol et al., 2009; Morán and Calvo-Diaz, 2009; Lasternas et al., 2010). These new approaches allow the characterization of the bacterial status at the individual-cell level and offer, as identified by Gasol et al. (2008), great potential to further our understanding on the variability of bacterial activity in aquatic systems, beyond the insights derived from previous approaches based on the examination of bulk assemblage properties.

Here, we examine the health status of heterotrophic bacteria in the NE subtropical Atlantic and test their hypothesized relationships with the status of photosynthetic plankton cells and the release of dissolved organic carbon. The phytoplankton and bacteria cell health status were investigated by quantifying the percentage of living and dying cells in communities across a range of oceanographic conditions from highly oligotrophic to productive waters in the NE subtropical Atlantic.

\section{Materials and methods}

\subsection{Study site and sampling}

This study was conducted in the subtropical NE Atlantic Ocean section during the RODA 2 cruise on board R/V Hespérides from 2 to 27 February 2007. A total of 23 stations were sampled: nine stations in the north Atlantic gyre area (Zone 1), eight placed in the vicinity of the Canary Current region (Zone 2), and six stations in the area influenced by Mauritania's upwelling (Zone 3; Fig. 1). At each station, vertical profiles of temperature, salinity, and fluorescence down to a $200 \mathrm{~m}$ depth were performed using a Seabird 911 Plus conductivity-temperature-depth (CTD) system. Seawater samples were collected in $12 \mathrm{~L}$ Niskin bottles mounted on a General Oceanics rosette sampler from seven depths from the surface to $200 \mathrm{~m}$. Seawater from the same CTD casts were used for the various samples performed during the cruise. Thus, samples for nutrient analysis (phosphate, nitrate + nitrite, ammonium, and silicate) were collected down to $200 \mathrm{~m}$. Samples for the determination of the dissolved inorganic phosphate concentrations and the nitrate + nitrite concentrations were kept frozen until analyzed in a Bran + Luebbe AA3 autoanalyzer following standard spectrophotometric methods (Hansen and Koroleff, 1999), and ammonium concentrations were measured spectrofluorometrically within $1 \mathrm{~h}$ of collection following Kérouel and Aminot (1997).

\subsection{Primary production and percentage of extracellular release (PER)}

In situ total primary production (TPP) and particulate primary production (PPP) was successfully measured using ${ }^{14} \mathrm{C}$ additions (Steemann-Nielsen, 1952) at 10 of the 23 stations of the study. Indeed, the rough sea and technical issues that occurred during the cruise prevented us from properly deploying the buoys for incubations at all the stations. Seawater sampled at five depths, including the surface $(5 \mathrm{~m})$, two intermediate depths, the deep chlorophyll maximum (DCM) and an ultimate depth below the DCM, was poured into transparent (light) and obscure (black masking tape-covered) polycarbonate bottles $(150 \mathrm{~mL})$ and inoculated with $80 \mu \mathrm{Ci}$ activity of a $\mathrm{NaH}^{14} \mathrm{CO}_{3}$ working solution. Inoculated bottles were set up at respective depths along a mooring buoy and incubated in situ for $4 \mathrm{~h}$ at the same time of the day (from 12:00 to 16:00), always including noon. As recommended by Morán and Estrada (2002), a short incubation period was used to optimize the measurements and minimize the contribution of trophic-related processes to DOC production. For each sample, two aliquots of $5 \mathrm{~mL}$ (replicates) were introduced in scintillation vials $(20 \mathrm{~mL})$ for the determination of 


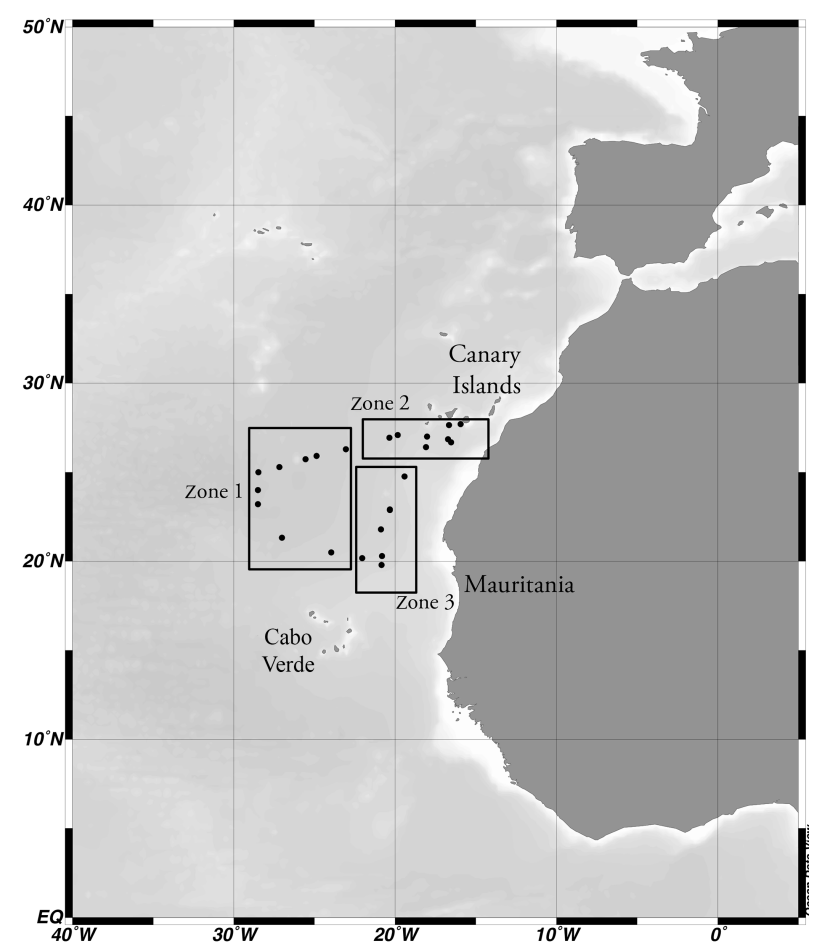

Figure 1. Areas of sampling and stations occupied during the RODA cruise. Zones 1, 2, and 3 correspond to three singular hydrographical and biological conditions: oligotrophic tropical Atlantic zone (Zone 1); intermediate Gran Canaria Current area (Zone 2); upwelling associated waters (Zone 3).

total labeled organic carbon production (TOC): the sum of ${ }^{14} \mathrm{C}$ incorporated into POC (particulate organic carbon), released as DOC. The remaining volume was filtered through $0.22 \mu \mathrm{m}$ mesh membrane filters (cellulose membrane filters) of $25 \mathrm{~mm}$ to determine PPP (PPP $>0.22 \mu \mathrm{m}$ ). To remove inorganic ${ }^{14} \mathrm{C}$, the liquid samples were acidified with $100 \mu \mathrm{L}$ of $10 \% \mathrm{HCl}$ and shaken for $12 \mathrm{~h}$, while the filters were fumed with concentrated $\mathrm{HCl}(37 \%)$ for $12 \mathrm{~h}$. Then, 10 and $5 \mathrm{~mL}$ of scintillation cocktail (Packard Ultima Gold XR) were respectively added to the TPP and PPP vials, and the disintegrations per minute were counted after $24 \mathrm{~h}$ with a scintillation counter (EG\&G Wallac). Disintegration per minute from dark incubations from particulate and total samples were subtracted from light particulate and total samples, respectively. The error of the measurements of TPP and PPP represented 14 and $9 \%$, respectively, in our study. The DOCp was calculated as the difference between total and particulate primary production (Morán et al., 2001) and the percentage of phytoplankton extracellular carbon release $(\mathrm{PER}=100 \mathrm{DOCp} / \mathrm{TPP})$ was calculated.

\subsection{Bacterioplankton abundance and viability}

At each station, the proportion of living heterotrophic bacteria was quantified from seawater sampled at up to seven depths (at the same CTD casts as before). To do so, we used the nucleic acid double-staining (NADS) (Grégori et al., 2001) flow cytometric protocol. This technique consists of the use of two nucleic acid fluorescent dyes, SYBR Green I (SG1; Molecular Probes) and propidium iodide (PI; Sigma Chemical Co.). Bacterial membranes are permeable to SG1, independent of the cell viability, resulting in green fluorescence when stained. However, living or viable cells with intact plasmic membranes are impermeable to PI. Thus, only compromised or damaged cells are stained with PI (Barbesti et al., 2000), showing red fluorescence as described in Falcioni et al. (2008). Subsamples were analyzed immediately after collection. Samples $(1 \mathrm{~mL})$ were stained with $10 \mu \mathrm{L}$ of Propidium iodide (PI, $1 \mathrm{mg} \mathrm{mL}^{-1}$ stock solution), reaching a final concentration of $10 \mu \mathrm{g} \mathrm{mL}^{-1}$ and incubated for $30 \mathrm{~min}$ in a dark room. Then, $10 \mu \mathrm{L}$ of SYBR Green I (10-fold dilution of $10000 \times$ commercial solution in dimethyl sulfoxide) was added to subsamples and incubated for 10 more minutes. SG1 and PI fluorescence were detected using a FACSCalibur flow cytometer (Beckton Dickinson) in the green (FL1) and the red (FL3) cytometric channels, respectively. Bivariate plots of green versus red fluorescence (FL1 vs. FL3) allowed for discrimination of live (green fluorescent, impermeable to PI) from dead cells (red fluorescent membranecompromised cells, stained by PI and SG1). Bacterial concentration was calculated using a $1 \mu \mathrm{m}$ diameter fluorescent bead solution (Polysciences, Inc.) as an internal standard. Total heterotrophic bacterial abundance was calculated as the sum of red and green fluorescent cell abundance, while living bacterial cell abundance was determined from the green fluorescent cell counts. In our study, errors due to including stained Prochlorococcus in the dead/living bacteria counts by NADS, represented less than $3 \%$ in the percentages of bacterial viability.

\subsection{Phytoplankton communities and viability of populations}

Water samples of $200 \mathrm{~mL}$ were filtered through Whatmann $\mathrm{GF} / \mathrm{F}$ filters to estimate total chlorophyll $a$ concentration $(\mathrm{Chl} a$ ) and extracted for $24 \mathrm{~h}$ in $90 \%$ acetone before fluorometric determination (Turner Designs fluorometer) following Parsons et al. (1984). Samples for the quantification of nanoand microphytoplankton abundance was sampled at the surface $(5 \mathrm{~m})$ and the DCM at each station, at the same casts as for the other parameters.

Microphytoplankton communities abundance were counted under epifluorescence microscope, and phototrophic picoplankton was counted on board on fresh samples by flow cytometry. The proportion of dead cells in the autotrophic communities examined was quantified by applying the cell digestion assay (CDA), a cell membrane permeability test consisting of the exposure of the phytoplankton communities to an enzymatic cocktail (DNAse and Trypsin, Agustí and Sánchez, 2002). Both enzymes are able to enter the 
cytoplasm and digests cells with compromised membranes (dead or dying cells), which are removed from the sample. The cells remaining in the sample after the CDA are living cells - those with intact membranes (Agustí and Sánchez, 2002) -, which are then counted by flow cytometry or epifluorescence microscope, as described above. For microphytoplankton counts and a viability test, samples of $2-3 \mathrm{~L}$ were concentrated into $50-70 \mathrm{~mL}$ samples using a Millipore cell concentration chamber. This concentration system has been used in previous studies (Alonso-Laíta and Agustí, 2006; Lasternas et al., 2010; Lasternas and Agustí, 2010) with accurate results for microphytoplankton and no effect on the viability or other cell properties (i.e., movement for flagellated cells, integrity of frustules, etc.). $10 \mathrm{~mL}$ aliquots (duplicates) of the concentrated sample were used as blanks for cell abundance quantification, and duplicated $10 \mathrm{~mL}$ aliquots of the cell concentrate were used to apply the CDA by adding $2 \mathrm{~mL}$ of DNAse I solution $-400 \mu \mathrm{g} \mathrm{mL}^{-1}$ in HBSS (Hanks' Balanced Salts) -, followed by a $15 \mathrm{~min}$ incubation at $35^{\circ} \mathrm{C}$ in a digital dry bath. After this time, $2 \mathrm{~mL}$ of trypsin solution ( $1 \%$ in HBSS) were added, followed by a $30 \mathrm{~min}$ incubation at $35^{\circ} \mathrm{C}$. At the end of this time, samples were placed in ice in order to stop the enzymatic cell digestion process. Both $10 \mathrm{~mL}$ aliquots (duplicates) from blanks and CDA samples were filtered onto $2 \mu \mathrm{m}$ pore-size black polycarbonate filters, with the samples from CDA washed several times with filtered seawater to remove the enzymes, then fixed with gluteraldehyde (1\% final concentration), and stored frozen at $-80^{\circ} \mathrm{C}$ until counting. Phytoplankton cells were counted using an epifluorescence microscope (Zeiss ${ }^{\odot}$ Axioplan Imaging), and were classified into three major groups: flagellates, dinoflagellates, and diatoms, which were then separated into pennate and centric. For phototrophic picoplankton abundance and cell viability, at each station fresh samples from seven depths were counted on board (duplicated counts) using a FACSCalibur Flow Cytometer (Beckton Dickinson). Duplicated $1 \mathrm{~mL}$ fresh samples without enzymes were used for blanks, and duplicated $1 \mathrm{~mL}$ fresh samples were used for the CDA following Agustí (2004), applying the same procedure as indicated above. An aliquot of a calibrated solution of $1 \mu \mathrm{m}$ diameter fluorescent beads (Polysciences Inc.) was added to the samples as an internal standard for the quantification of cell concentration. The red (FL3; bandpass filter: $>670 \mathrm{~nm}$ ), green (FL1; bandpass filter: $530 \mathrm{~nm}$ ) and orange (FL2; bandpass filter: $585 \mathrm{~nm}$ ) fluorescence and the forward and side scattering signals of the cells and beads were used to detect phototrophic picoplankton populations of Synechococcus, Prochlorococcus, and autotrophic picoeukaryotes (Marie et al., 2005). The percentage of dead cells was calculated for the different phytoplankton taxonomic groups within micro-, nano-, and phototrophic picoplankton populations, from the ratio between the concentration of dead cells (total concentration minus the concentrations of living cells) and total population abundance, which includes both living and death cells (Agustí and Sánchez, 2002). The incubation time and concentration of enzymes of the CDA were tested to be sufficiently efficient for the digestion of different phytoplankton groups (Agustí and Sánchez, 2002). Also, it was checked in previous studies using blank samples that the incubation procedure does not reduce the initial abundance of cells (Agustí and Sánchez, 2002; Agustí, 2004). We do not recommend the CDA for studying bacterial viability in natural communities because staining is required to quantify heterotrophic bacteria. If there is the need to stain cells after the CDA, Darzynkiewicz et al. (1994) recommended washing the samples after the enzymatic test to remove the enzymes, and resuspending cells in culture media until the complete recovery of the membranes' coats before adding the stain. This procedure is not feasible with natural bacterial samples, and we better recommend the use of double vital staining methods, such as the NADS (Grégori et al., 2001) used in this study, to quantify heterotrophic bacteria viability. Moreover, although the CDA was successful when applied to analyze cell viability in diatom and cyanobacteria colonies (Agustí et al., 2006), we also do not recommend the use of the CDA method to quantify the viability of multicellular organisms as zooplankton. To inform oneself about the health state of an invertebrate using the CDA (e.g., copedods, Zetsch and Meysman, 2012), one must count the individual cells within the organism before (living and dead cells) and after the application of the CDA (only living cells), which is not feasible without tissue disruption. Also, the CDA is not a qualitative method but a quantitative one. The CDAs provide valuable results only after quantification of cells in control samples (without enzymes) and quantification of remaining living cells in samples exposed to the CDA enzymatic cocktail (living cells remained). Non-quantitative applications of the method (Zetsch and Meysman, 2012) or results without informing oneself of quantitative data are not appropriate uses for this method.

\subsection{Statistics}

Spearman's rank coefficients were used to determine correlation coefficients between variables that departed from normality (Siegel and Castellan, 1988). The averages and standard error were calculated from the whole data set of each parameter and average ratios were calculated as the average of ratios. The statistical significance of the differences between average values was tested using the Wilcoxon signedrank test, with a critical $p$ value of 0.05 . Linear regression analyses were applied to raw data.

\section{Results}

The waters studied included three distinct oceanographic zones (Fig. 1): the oligotrophic subtropical Atlantic Ocean, which presented significantly warmer and saltier waters and 
Table 1. Average \pm SE hydrological properties, nutrients and chlorophyll $a$ concentration, primary production rates, percentage of phytoplankton extracellular carbon release (PER), health status of phytoplankton and heterotrophic bacteria and DOC flux per bacteria cell quantified at the three zones. The average values for the zones connected by the same letter are not significantly different (Wilcoxon signedrank test, $p<0.05)$, and those for the zones connected by a different letter are significantly different $(p<0.05)$.

\begin{tabular}{|c|c|c|c|}
\hline Mean $\pm \mathrm{SE}$ & Oligotrophic & Intermediate & Upwelling \\
\hline Temperature $\left({ }^{\circ} \mathrm{C}\right)$ & $21.46 \pm 0.16^{\mathrm{A}}$ & $19.15 \pm 0.16^{\mathrm{C}}$ & $19.94 \pm 0.22^{\mathrm{B}}$ \\
\hline Salinity (PSU) & $37.21 \pm 0.04^{\mathrm{A}}$ & $36.87 \pm 0.03^{\mathrm{B}}$ & $36.74 \pm 0.04^{\mathrm{C}}$ \\
\hline Dissolved inorganic nitrogen $\left(\mu \mathrm{molNL} \mathrm{N}^{-1}\right)$ & $0.31 \pm 0.06^{\mathrm{B}}$ & $0.75 \pm 0.15^{\mathrm{B}}$ & $2.28 \pm 0.41^{\mathrm{A}}$ \\
\hline Ammonium $\left(\mu \mathrm{molNL} \mathrm{NL}^{-1}\right)$ & $0.10 \pm 0.01^{\mathrm{B}}$ & $0.11 \pm 0.01^{\mathrm{AB}}$ & $0.13 \pm 0.01^{\mathrm{A}}$ \\
\hline Phosphate $\left(\mu \mathrm{molPL}{ }^{-1}\right)$ & $0.21 \pm 0.03^{\mathrm{AB}}$ & $0.09 \pm 0.02^{\mathrm{B}}$ & $0.33 \pm 0.03^{\mathrm{A}}$ \\
\hline Chlorophyll (mg Chl $a \mathrm{~m}^{-3}$ ) & $0.28 \pm 0.02^{\mathrm{B}}$ & $0.37 \pm 0.04^{\mathrm{AB}}$ & $0.48 \pm 0.05^{\mathrm{A}}$ \\
\hline Total primary production $\left(\mathrm{mg} \mathrm{Cm}^{-3} \mathrm{~h}^{-1}\right)$ & $0.70 \pm 0.10^{\mathrm{A}}$ & $0.96 \pm 0.13^{\mathrm{A}}$ & $1.14 \pm 0.20^{\mathrm{A}}$ \\
\hline Dissolved organic carbon production by phytoplankton $\left(\mathrm{mg} \mathrm{Cm}^{-3} \mathrm{~h}^{-1}\right)$ & $0.58 \pm 0.09^{\mathrm{A}}$ & $0.64 \pm 0.10^{\mathrm{A}}$ & $0.41 \pm 0.09^{\mathrm{A}}$ \\
\hline PER & $81.9 \pm 1.9^{\mathrm{A}}$ & $64.4 \pm 4.7^{\mathrm{B}}$ & $41.3 \pm 7.9^{\mathrm{C}}$ \\
\hline Phytoplankton dead cells (\%DC) & $51.9 \pm 4.2^{\mathrm{A}}$ & $39.1 \pm 2.7^{\mathrm{B}}$ & $44.1 \pm 4.4^{\mathrm{B}}$ \\
\hline Heterotrophic living bacteria (\%HLB) & $85.7 \pm 1.1^{\mathrm{A}}$ & $79.9 \pm 0.9^{\mathrm{B}}$ & $74.8 \pm 1.0^{\mathrm{C}}$ \\
\hline Flux of DOC per bacteria cell $\left(\mathrm{pg} \mathrm{C}\right.$ cell $\left.^{-1} \mathrm{~h}^{-1}\right)$ & $1.82 \pm 0.42^{\mathrm{A}}$ & $1.59 \pm 0.24^{\mathrm{AB}}$ & $0.81 \pm 0.21^{\mathrm{B}}$ \\
\hline
\end{tabular}

Table 2. Average \pm SE of the nano-/microphytoplankton abundances in the three zones.

\begin{tabular}{lccc}
\hline Mean $\left(\right.$ cells $\left.L^{-1}\right) \pm \mathrm{SE}$ & Oligotrophic & Intermediate & Upwelling \\
\hline Nano-microphytoplankton & $2.22 \pm 0.31 \times 10^{3}$ & $2.83 \pm 0.38 \times 10^{3}$ & $5.89 \pm 1.54 \times 10^{3}$ \\
Flagellates & $1.09 \pm 0.22 \times 10^{3}$ & $1.53 \pm 0.11 \times 10^{3}$ & $2.78 \pm 0.74 \times 10^{3}$ \\
Diatoms & $5.18 \pm 0.76 \times 10^{2}$ & $8.41 \pm 1.26 \times 10^{2}$ & $2.23 \pm 0.72 \times 10^{3}$ \\
Dinoflagellates & $6.09 \pm 0.15 \times 10^{2}$ & $4.63 \pm 1.68 \times 10^{2}$ & $8.77 \pm 3.02 \times 10^{2}$ \\
\hline
\end{tabular}

low nutrient concentration (Table 1); waters influenced by the NW African upwelling system, characterized by cooler and fresher waters, higher dissolved nutrient concentration, and higher chlorophyll $a$ concentrations (Table 1); the transitional system around the Canary Islands, influenced by the Canary current, exhibiting intermediate temperature, salinity, and nutrient concentration (Table 1). We also observed a significant trend between chlorophyll $a$ concentrations and depth, independent of the zone of sampling (Fig. 2).

Maximum TPP was found at the waters influenced by the upwelling $\left(2.68 \pm 0.03 \mathrm{mg} \mathrm{Cm}^{-3} \mathrm{~h}^{-1}\right.$ at station \#8 $21^{\circ} 49^{\prime} \mathrm{N} / 20^{\circ} 52^{\prime} \mathrm{W}$ ) and the lowest values at the oligotrophic zone, although differences in the averaged values were not significant between the three zones (Table 1). Dissolved primary production $\left(\mathrm{DOC}_{\mathrm{p}}\right)$ was positively related to total primary production $\left(\mathrm{TPP} ; \log \mathrm{DOC}_{\mathrm{p}}=-0.501+0.92( \pm 0.09)\right.$ $\log$ TPP, $R^{2}=0.68, P<0.001, N=45$ ), and tended to increase as total primary production increased, but with a slope slightly lower than 1 , indicating that $\mathrm{DOC}_{\mathrm{p}}$ tended to be proportionally lower in productive waters (Table 1). Thus, the percentage of phytoplankton extracellular carbon release (PER), which varied greatly across the study (Table 1), was greatest in the most oligotrophic waters sampled and declined towards more productive waters (Table 1).

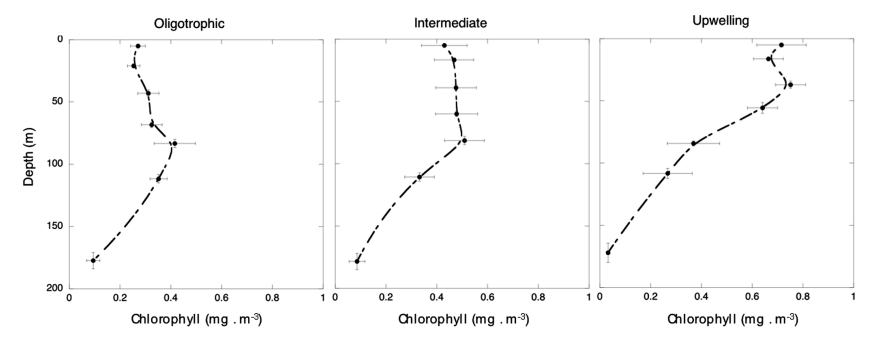

Figure 2. Profile plots showing the relationships between chlorophyll $a$ concentrations and depth by zones of sampling.

Nano-microphytoplankton communities were present along the study site, and showed higher abundance at the DCM than at the surface waters, with slightly higher abundance within Zone 3, the area influenced by the upwelling system (Table 2). Autotrophic flagellates dominated the microphytoplanktonic community throughout the study (Table 2) and presented relatively uniform abundance within the studied zones. Diatoms were sparse within Zone 1 (Table 2), represented almost solely by the pennate genera Nitzschia spp., but showed a consistent increase in abundance at the waters influenced by the upwelling (Zone 3, Table 2), with the centric genera Thalassiosira sp. and Chaetoceros sp. being the most abundant. Dinoflagellates, 

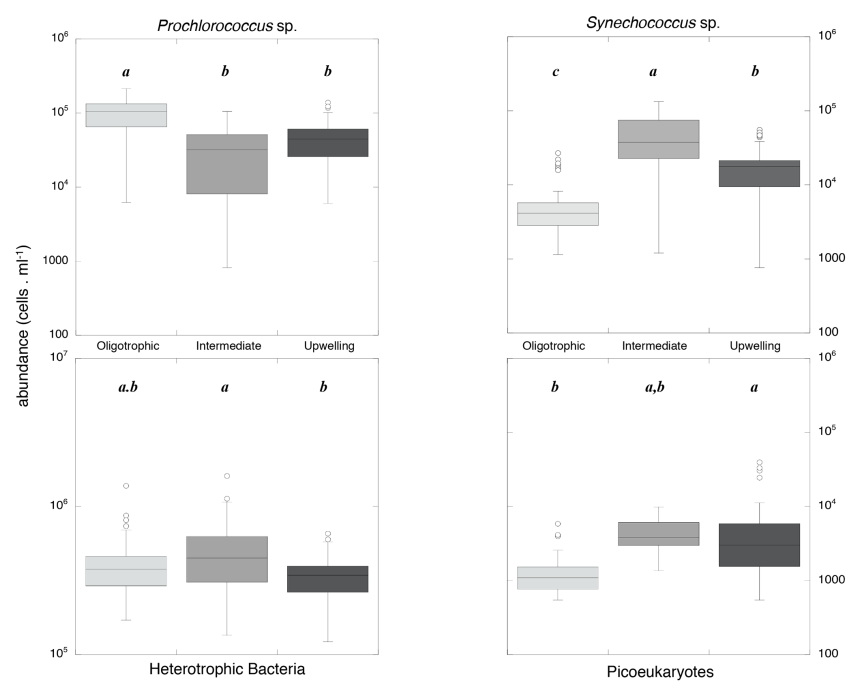

Figure 3. Box plots showing the abundance distribution of the picoplankton populations within systems. The boxes show the lower and upper quartiles, median, minimum, and maximum values, and outliers. Numbers correspond to averaged $( \pm$ SE) abundances within systems. The boxes connected by same letter are not significantly different (Wilcoxon signed-rank test, $p<0.05$ ).

primarily represented by the naked form Gymnodinium spp., displayed low abundance across the cruise (Table 2), and were principally located in surface waters.

Prochlorococcus spp., the most abundant phytoplankton detected during the cruise (Fig. 3), presented significant higher values than both populations of Synechococcus spp. and picoeukaryotes at Zones 1 and 2, and decreased at waters associated to the upwelling system (Zone 3). Within this zone, the Synechococcus spp. abundance surpassed that of Prochlorococcus spp. (Fig. 3). Picoeukaryotes's abundance was relatively uniform (about $10^{3}$ cells $\mathrm{mL}^{-1}$ ) between the three zones of study, with maximum values observed at the intermediate zone of the Canary current (Zone 2, Fig. 3). Heterotrophic bacteria presented a significantly higher abundance at the oligotrophic zone (Zone 1) and a lower one at Zone 2 (Fig. 2).

The percentage of dead phytoplankton cells (\%DC) varied greatly across communities (Fig. 4, Table 1). Diatoms dominated the communities in the upwelling area (Table 2), where they showed a low proportion of dead cells, with the highest percentage of dead diatom cells observed in oligotrophic waters (Fig. 4). Prochlorococcus spp., the dominant phototrophic picoplankton taxa (Table 2), was less abundant and presented a higher proportion of dead cells in the upwelling zone (Figs. 3 and 4). The oligotrophic zone presented the highest phytoplankton mortality (Table 1) associated with the highest PER rates. The variability in the percentage of phytoplankton extracellular carbon release in each station was closely dependent on the status of the photosynthetic community, as reflected in a linear increase in the percentage of
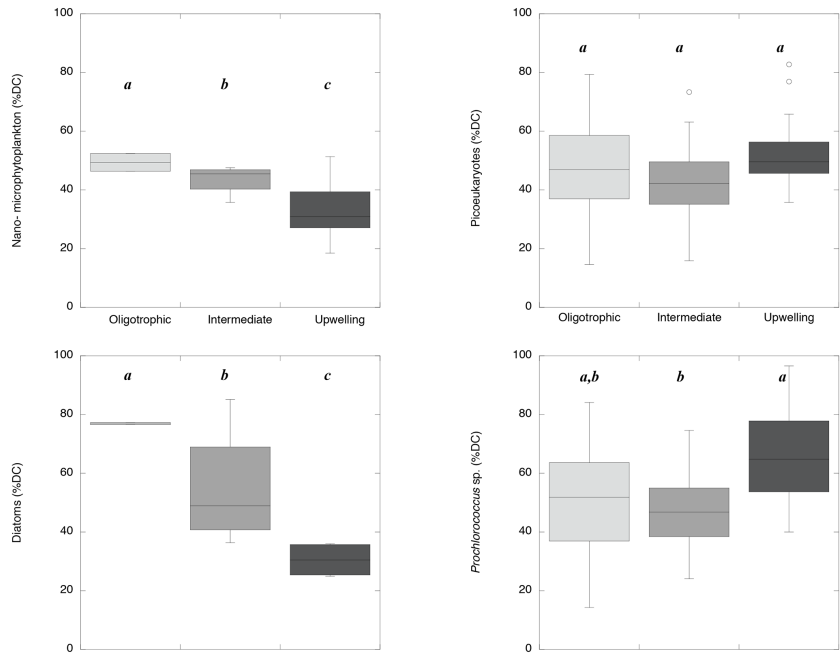

Figure 4. Box plots showing the distribution percentage of dead phytoplankton cells (\%DC) of the different phytoplankton group in the sampled zones. The boxes present the lower and upper quartiles, median, minimum, and maximum values, and outliers. The boxes showing the same letter do not have significantly different mean values (Mann-Whitney-Wilcoxon test, $p<0.005$ ).

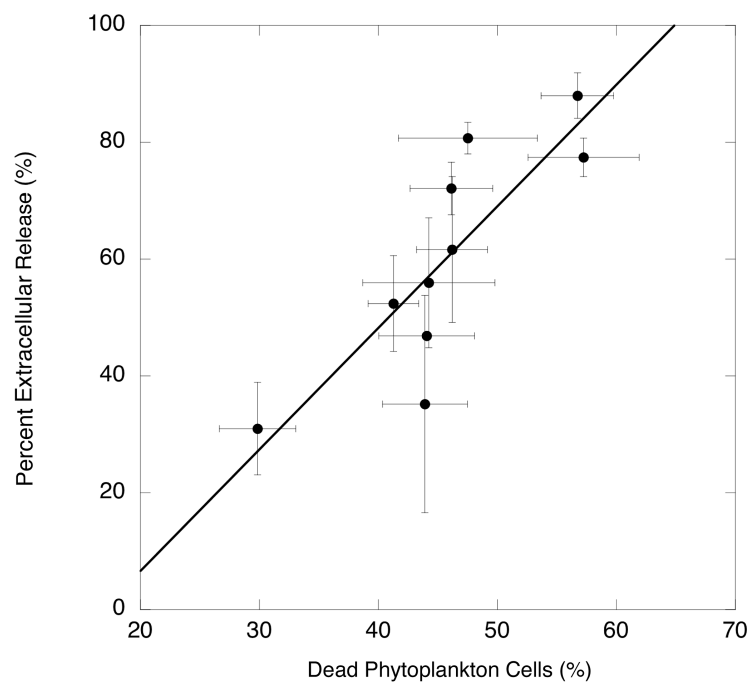

Figure 5. The relationship between the percentage of dead phytoplankton cells (\%DC) and the percentage of phytoplankton extracellular carbon release (PER), averaged by stations across the study. The full line represents the fitted regression equation: PER $=-35.03+2.08( \pm 0.49)$ phytoplankton \%DC $\left(R^{2}=0.69\right.$, $P=0.0029, N=10)$.

phytoplankton extracellular carbon release with an increase in the percentage of dead cells in the photosynthetic community (Fig. 5).

Bacterial viability varied between 60 and $95 \%$ of living cells and the average of the percentage of living heterotrophic bacteria cells was higher than that of 

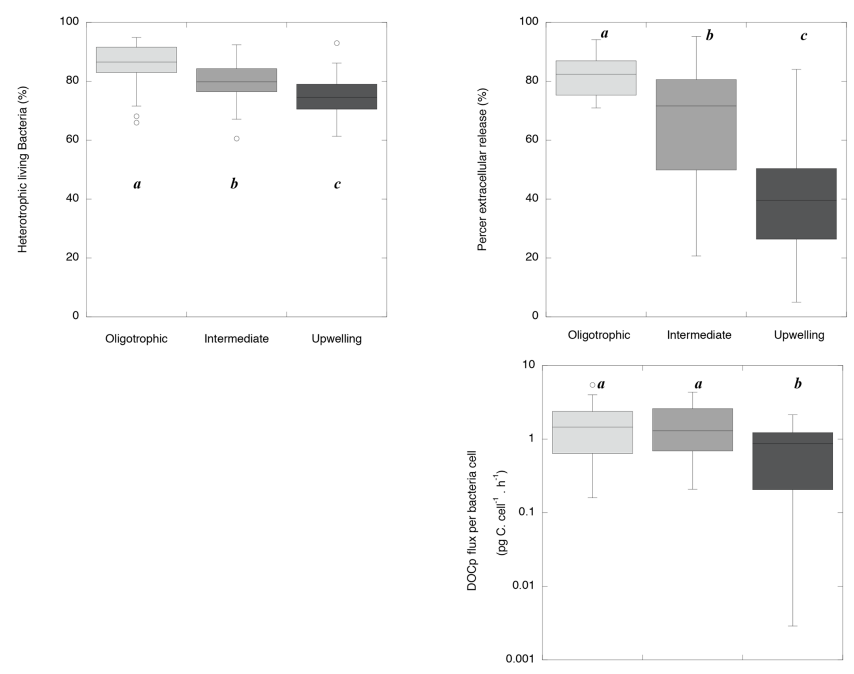

Figure 6. Box plots showing the distribution of the percentage of living bacteria cells, the distribution of PER (percentage of phytoplankton extracellular carbon release) and the variation of fluxes of $\mathrm{DOC}_{\mathrm{p}}$ per bacteria at the three sampled zones. The boxes present the lower and upper quartiles, median, minimum, and maximum values, and outliers. The boxes showing the same letter do not have significantly different mean values (Wilcoxon signed-rank test, $p<0.05)$.

autotrophicpicoplankton (Wilcoxon signed-rank test, $P<$ 0.0001). While bacterioplankton presented the highest abundance in the intermediate waters, the percentage of heterotrophic living bacteria was lowest in the most productive waters and tended to decrease towards more oligotrophic waters (Fig. 6, Table 1). By dividing the production of dissolved organic carbon by phytoplankton and the bacterial total abundance, we obtained the flux of DOCp per bacterial cell $\left(\mathrm{pg}\right.$ C bacterial cell $\left.{ }^{-1} \mathrm{~h}^{-1}\right)$ and could determine that availability in DOC for heterotrophic bacteria was higher in the oligotrophic and intermediate waters (Fig. 6) than at those influenced by the upwelling. The percentage of living heterotrophic bacterioplankton cells was significantly positively related to the proportion of extracellular dissolved organic carbon released $(\% \mathrm{LC}=71.6+0.16$ PER; $P<0.0001, R^{2}=0.35$, Fig. 7).

\section{Discussion}

The results presented here provide evidence of a close coupling between the heterotrophic bacterial health status and the release of recently photosynthesized carbon by phytoplankton in the NE subtropical Atlantic. The results presented also suggest a mechanistic pathway linking phytoplankton cell death with high phytoplankton extracellular carbon release and a subsequent increase in the percentage of living heterotrophic bacteria cells. These results confirm the power of approaches based on assessments at the single-

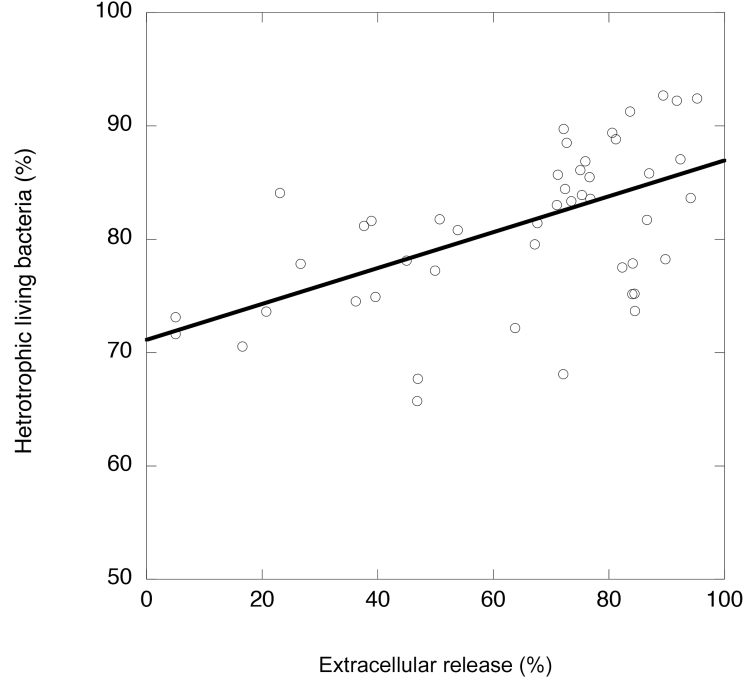

Figure 7. The relationship between the percentage of living heterotrophic bacteria and the percentage of extracellular dissolved organic carbon release. The open symbols represent the individual percentage of living bacteria and the full line represents the fitted regression equation between the percentage living heterotrophic bacteria and PER $\left(\% \mathrm{LC}=71.6+0.16 \mathrm{PER} ; P<0.0001, R^{2}=0.35\right)$.

cell level (Agustí and Sánchez, 2002; Bidle and Falkowki, 2004; Gasol et al., 2008; Lasternas et al., 2010) to resolve the relationships between the status of phytoplankton cells and that of heterotrophic bacteria, mediated by the extracellular release of organic carbon.

Previous attempts at testing the response of the bacterial community (metabolism and/or physiological status) to DOCp release were conducted among systems but remained elusive and variable. For instance, in open-ocean sites, bacterial production and dissolved primary production (DPP) are often tightly linked (Morán et al., 2001; Antarctic off shore waters), while in coastal (Morán et al., 2002a; NE Atlantic coastal system, Morán et al., 2002b) or eutrophic sites (Baines and Pace, 1991; Morán et al., 2002b, Antarctic coastal) persists a lack of linkage. Our study provides, to the best of our knowledge, the first demonstration of a direct relationship between recently released labile photosynthate, the preferred carbon source for heterotrophic bacteria (Norrman et al., 1995), and the bacterial health status expressed as the percentage of living bacterial cells.

A gradient in phytoplankton productivity and community structure from the African upwelling region to the oligotrophic region offshore has been previously reported for the subtropical NE Atlantic (Teira et al., 2003; Pelegrí et al., 2005; Alonso-Laíta and Agustí, 2006), including an increase in phytoplankton mortality rates and the proportion of dead phytoplankton cells along this gradient (Agustí et al., 2001; Alonso-Laíta and Agustí, 2006). The results presented here confirm these findings, with phytoplankton cell viability decreasing from upwelling-influenced waters to 
oligotrophic waters, particularly for diatoms, which showed a two-fold reduction in the percentage of living cells from the upwelling to the oligotrophic waters. However, the patterns displayed by the different populations composing the phytoplankton community were complex, as phytoplankton show intricate and differentiated niches of cell viability depending on cell size, irradiance, nutrient concentration, and temperature (Berges and Flakowski, 1998; Agawin et al., 2000; Agustí, 2004; Alonso-Laiìta and Agustí, 2006; Agustí and Llabrés, 2007; Lasternas et al., 2010). The percentage of dead cells tended to increase with decreasing cell size, with more than $40 \%$ of dead cells generally found in the phototrophic picoplankton community. There is a reported increase in mortality rates with decreasing cell size (Marbá et al., 2007), which is consistent with a larger population turnover for picophytoplankton. Although phototrophic picoplankton communities are typically dominant in oligotrophic waters (Agawin et al., 2000), they showed high variability in cell viability in the most oligotrophic waters sampled here. Surface populations are exposed to high PAR and UV radiation, resulting in high \%DC of Prochlorococcus spp., which is strongly sensitive to high solar radiation (Llabrés and Agustí, 2006; Agustí and Llabrés, 2007; Llabrés et al., 2010), whereas Synechococcus is typically stressed by low light at deep layers, but shows higher cell survival in surface waters (Agustí, 2004; Llabrés and Agustí, 2006). In addition, the high cell mortality of Prochlorococcus sp. in the upwelling waters is consistent with the incapacity of Prochlorococcus sp. to use nitrate (Moore et al., 2002) and with the decline in cell viability in waters below $21^{\circ} \mathrm{C}$ (Alonso-Laíta and Agustí, 2006).

The patterns of cell survival of the natural phytoplankton populations described here provided compelling evidence that the variation in the proportion of dissolved organic carbon release is driven by phytoplankton cell mortality in the subtropical NE Atlantic Ocean. In agreement with previous studies, communities in unproductive oligotrophic waters tended to release, as DOC, a higher fraction of their total primary production compared to more productive, nutrient-rich upwelling waters (Teira et al., 2001; Morán et al., 2002a). Moreover, the mortality among the microphytoplanktonic groups supported a higher release of primary production as dissolved organic carbon. In turn, in the upwelling zone, the microphytoplankton supported a larger biomass and a consequently higher carbon flux through bacteria compared to the oligotrophic or intermediate waters.

Within the upwelling-influenced area of the NE Atlantic Ocean, bacterial communities have been identified to be carbon-limited (Alonso-Sáez et al., 2007). In our study, we found higher bacterial abundance in intermediate and oligotrophic waters offshore, consistent with higher values of DOC released by phytoplankton, slightly declining towards the waters influenced by the upwelling. The PER was, however, lowest at the upwelling-influenced area and, accordingly, the supply of dissolved organic carbon per bacterial cell was lowest at the upwelling-influenced area. Indeed, the patterns in the health status of bacteria cells was consistent with the supply of dissolved organic carbon per cell, both being highest in the oligotrophic, compared to the more productive, waters. This is in agreement with the carbon limitation of the bacterial community in the upwelling-influenced waters reported by Alonso-Sáez et al. (2007). High bacterial viability was observed in the oligotrophic waters, where phytoplankton released a much higher proportion of their production as DOC, resulting in a higher flux of DOCp per bacterial cell. This finding is also in agreement with reports of a strong dependence of bacteria on algal extracellular production in open-ocean environments, while bacterial carbon demand was not related to algal $\mathrm{DOC}_{\mathrm{p}}$ in coastal and productive systems (Morán et al., 2002a, b). In oligotrophic areas, allochthonous organic matter from lateral transfer or atmospheric inputs can be an alternative source of carbon to autochthonous production (del Giorgio et al., 1997; Arístegui et al., 2003 Herndl et al., 2008). Accordingly, DOC freshly released by phytoplankton is the source of carbon supporting the most efficient assimilation by bacteria in the oligotrophic ocean (Coveney and Wetzel, 1989; Norrman et al., 1995). Moreover, the lability of the compounds released by phytoplankton may also change depending on the phytoplankton composition and that would differentially affect bacterial responses (Nelson and Carlson, 2012). Indeed, recent studies showed that the community structure of heterotrophic prokaryotes tends to respond to differences in the quality of organic matter released among microalgal species (Sarmento et al., 2013). In our study, while we were not able to specify the quality of the $\mathrm{DOC}_{\mathrm{p}}$ released by the phytoplankton community, our results address the positive response of the bacterial viability to the increasing in DOCp production by phytoplankton.

Our results support high phytoplankton cell death in the oligotrophic ocean, consistent with previous findings (Agustí, 2004; Alonso-Laiìta and Agustí, 2006; Lasternas et al., 2010, 2013), and demonstrate that high phytoplankton cell death in the open oligotrophic areas of the NE Atlantic results in a large release of DOC relative to primary production, providing a significant flux of labile carbon, that results in a healthier heterotrophic bacteria status, as demonstrated by the relationship between the percentage of living heterotrophic bacteria viability and PER presented here.

Acknowledgements. This research is a contribution to the project RODA (CTM-2004-06842-CO3-O2) and to the project StressX (CTM2012-32603), funded by the Spanish Ministry of Economy and Competitiveness. We thank C. M. Duarte for useful comments on the manuscript and the nutrient concentrations provided.

Edited by: K. Suzuki 


\section{References}

Agawin, N. S. R., Duarte, C. M., and Agustí, S.: Nutrient and temperature control of the contribution of picoplankton to phytoplankton biomass and production, Limnol. Oceanogr., 45, 591-600, 2000.

Agustí, S.: Viability and niche segregation of Prochlorococcus and Synechococcus cells across the Central Atlantic Ocean, Aquat. Microb. Ecol., 36, 53-59, doi:10.3354/ame036053, 2004.

Agustí, S., Alou, E., Hoyer, M. V., Frazer, T. K., and Canfield, D. E.: Cell death in lake phytoplankton communities, Freshwater Biol., 51, 1496-1506, 2006

Agustí, S. and Duarte, C. M.: Strong seasonality in phytoplankton cell lysis in the NW Mediterranean littoral, Limnol. Oceanogr., 45, 940-947, 2000.

Agustí, S. and Duarte, C. M.: Phytoplankton lysis predicts dissolved organic carbon release in marine plankton communities, Biogeosciences, 10, 1259-1264, doi:10.5194/bg-10-1259-2013, 2013.

Agustí, S. and Llabrés, M.: Solar radiation-induced mortality of marine pico-phytoplankton in the oligotrophic ocean, Photochem. Photobiol., 83, 793-801, doi:10.1111/j.17511097.2007.00144.x, 2007.

Agustí, S. and Sánchez, M. C.: Cell viability in natural phytoplankton communities quantified by a membrane permeability probe, Limnol. Oceanogr., 47, 818-828, 2002.

Agustí, S., Satta, M. P., Mura, M. P., and Benavent, E.: Dissolved esterase activity as a tracer of phytoplankton lysis: evidence of high phytoplankton lysis rates in the North Western Mediterranean, Limnol. Oceanogr., 43, 1836-1849, 1998.

Agustí, S., Duarte, C. M., Vaqué, D., Hein, M., Gasol, J. M., and Vidal, M.: Food-web structure and elemental (C, N and P) fluxes in the eastern tropical North Atlantic, Deep-Sea Res Pt. II, 48, 2295-2321, doi:10.1016/S0967-0645(00)00179-x, 2001.

Alonso-Laíta, P. and Agustí, S.: Contrasting patterns of phytoplankton viability in the subtropical NE Atlantic Ocean, Aquat. Microb. Ecol., 43, 67-78, doi:10.3354/ame043067, 2006.

Alonso-Sáez, L., Gasol, J. M., Arístegui, J., Vilas, J. C., Vaqué, D., Duarte, C. M., and Agustí, S.: Large-scale variability in surface bacterial carbon demand and growth efficiency in the subtropical Northeast Atlantic Ocean, Limnol. Oceanogr., 52, 533-546, 2007

Arístegui, J., Barton, E. D., Montero, M. F., García-Muñoz, M., and Escánez, J.: Organic carbon distribution and water column respiration in the NW Africa-Canaries Coastal Transition Zone, AME, 33, 289-301, 2003.

Azam, F.: Microbial control of oceanic carbon flux: the plot thickens, Science, 280, 694-696, doi:10.1126/science.280.5364.694, 1998.

Azam, F., Fenchel, T., Field, J. G., Gray, J. S., Meyer-Reil, L. A., and Thingstad, F.: The ecological role of water-column microbes in the sea, Mar. Ecol.-Prog. Ser., 10, 257-263, 1983.

Baines, S. B. and Pace, M. L.: The production of dissolved organic matter by phytoplankton and its importance to bacteria: Patterns across marine and freshwater systems, Limnol. Oceanogr., 36, 1078-1090, 1991.

Barbesti, S., Citterio, S., Labra, M., Baroni, M. D., Neri, M. G., and Sgorbati, S.: Two and three-color fluorescence flow cytometric analysis of immunoidentified viable bacteria, Cytometry, 40, 214-218, doi:10.1002/10970320(20000701)40:3<214::AID-CYTO6>3.0.CO;2-M, 2000.
Becker, J. W., Berube, P. M., Follett, C. L., Waterbury, J. B., Chisholm, S. W., DeLong, E. F., and Repeta, D. J.: Closely related phytoplankton species produce similar suites of dissolved organic matter, Front. Microbiol., 5, 111, doi:10.3389/fmicb.2014.00111, 2014.

Berges, J. A. and Falkowski, P. G.: Physiological stress and cell death in marine phytoplankton: induction of proteases in response to nitrogen or light limitation, Limnol. Oceanogr., 43, 129-135, 1998.

Bidle, K. D. and Falkowski, P. G.: Cell death in planktonic, photosynthetic microorganisms, Nat. Rev. Microbiol., 2, 643-655, doi:10.1038/nrmicro956, 2004.

Brussaard, C. P. D., Riegman, R., Noordeloos, A. A. M., Cadée, G. C., Witte, H., Kop, A. J., Nieuwland, G., Van Duyl, F. C., and Bak, R. P. M.: Effects of grazing, sedimentation and phytoplankton cell lysis on the structure of a coastal pelagic food web, Mar. Ecol.-Prog. Ser., 123, 259-271, 1995.

Carlson, C. A. and Ducklow, H. W.: Growth of bacterioplankton and consumption of dissolved organic carbon in the Sargasso Sea, Aquat. Microb. Ecol., 10, 69-85, doi:10.3354/ame010069, 1996.

Choi, J. W., Sherr, E. B., and Sherr, B. F.: Relation between presence-absence of a visible nucleoid and metabolic activity in bacterioplankton cells, Limnol. Oceanogr., 41, 1161-1168, 1996.

Cole, J. J., Findlay, S., and Pace, M. L.: Bacterial production in fresh and saltwater ecosystems: a cross-system overview, Mar. Ecol.-Prog. Ser., 3, 1-10, 1988.

Coveney, M. F. and Wetzel, R. G.: Bacterial metabolism of algal extracellular carbon, Hydrobiologia, 173, 141-149, 1989.

Darzynkiewicz, Z., Li, X., and Gong, J.: Assays of cell viability: Discrimination of cells dying by apoptosis, in: Methods in cell biology, edited by: Darzynkiewicz, Z., Robinson, J. P., and Crissman, H. A., Academic Press, Inc., San Diego, 1994.

del Giorgio, P. A., Cole, J. J., and Cimberis, A.: Respiration rates of bacteria exceed phytoplankton in unproductive aquatic systems, Nature, 385, 148-151, doi:10.1038/385148a0, 1997.

Ducklow, H.: Bacterial production and biomass in the oceans, in: Microbial Ecology of the Oceans, edited by: Kirchman, D., Wiley, New York, 85-120, 2000.

Falcioni, T., Papa, S., and Gasol, J. M.: Evaluating the flowcytometric nucleic acid double-staining protocol in realistic situations of planktonic bacterial death, Appl. Environ. Microbiol., 74, 1767-1779, doi:10.1128/aem.01668-07, 2008.

Fogg, G. E.: Aquatic primary production in the Antarctic, Philos. T. Roy. Soc. B., 279, 27-38, 1977.

Fuhrman, J. A.: Bacterioplankton roles in cycling of organic matter: the microbial food web, in: Primary Productivity and Biogeochemical Cycles in the Sea, edited by: Falkowski, P. G. and Woodhead, A. D., Plenum Press, New York, 361-383, 1992.

Gasol, J. M., Pinhassi, J., Alonso-Sáez, L., Ducklow, H., Herndl, G. J., Koblízek, M., Labrenz, M., Luo, Y., Morán, X. A. G., Reinthaler, T., and Meinhard, S.: Towards a better understanding of microbial carbon flux in the sea, Aquat. Microb. Ecol., 53, 21-38, doi:10.3354/ame01230, 2008.

Gasol, J. M., Alonso-Sáez, L., Vaqué, D., Baltar, F., Calleja, M. L., Duarte, C. M., and Arístegui, J.: Mesopelagic prokaryotic bulk and single-cell heterotrophic activity and community composition in the NW Africa-Canary Islands coastal-transition zone, Prog. Oceanogr., 83, 189-196, doi:10.1016/j.pocean.2009.07.014, 2009. 
Grégori, G., Citterio, S., Ghiani, A., Labra, M., Sgorbati, S., Brown, S., and Denis, D.: Resolution of viable and membranecompromised bacteria in freshwater and marine waters based on analytical flow cytometry and nucleic acid double staining, Appl. Environ. Microb., 67, 4662-4670, doi:10.1128/AEM.01668-07, 2001

Hansen, H. P. and Koroleff, E.: Determination of nutrients, in: Methods of Seawater Analysis, edited by: Grasshoff, K., Kremling, K., and Ehrhardt, M., Weinheim, Wiley-VCH Verlag, 159-228, 1999.

Herndl, G. J., Brugger, A., Hager, S., Kaiser, E., Obernosterer, I., Reitner, B., and Slezak, D.: Role of ultraviolet-B radiation on bacterioplankton and the availability of dissolved organic matter, Plant Ecol., 128, 43-51, 1997.

Herndl, G. J., Agogué, H., Baltar, F., Reinthaler, T., Sintes, E., and Varela, M. M.: Regulation of aquatic microbial processes: the "microbial loop" of the sunlit surface waters and the dark ocean dissected, AME, 53, 59-68, doi:10.3354/ame01225, 2008.

Karl, D. M., Hebel, D. V., Bjorkman, K., and Letelier, R. M.: The role of dissolved organic matter release in the productivity of the Oligotrophic North Pacific Ocean, Limnol. Oceanogr., 43, 1270-1286, 1998.

Kérouel, R. and Aminot, A.: Fluorometric determination of ammonia in sea and estuarine waters by direct segmented flow analysis, Mar. Chem., 57, 265-275, 1997.

Kirchman, D. L.: Microbial breathing lessons, Nature, 385, 121-122, doi:10.1038/385121a0, 1997.

Kirchman, D. L., Suzuki, Y., Garside, C., and Ducklow, H. W.: High turnover rates of dissolved organic carbon during a spring phytoplankton bloom, Nature, 352, 612-614, doi:10.1038/352612a0, 1991.

Kirchman, D. L., Dittel, A. I., Findlay, S. E. G., and Fischer, D.: Changes in bacterial activity and community structure in response to dissolved organic matter in the Hudson River, New York, Aquat. Microb. Ecol., 35, 243-257, doi:10.3354/ame035243, 2004.

Lasternas, S. and Agustí, S.: Phytoplankton community structure during the record Arctic ice-melting of summer 2007, Polar Biol., 33, 1709-1717, doi:10.1007/s00300-010-0877-x, 2010

Lasternas, S., Agustí, S., and Duarte, C. M.: Phyto- and bacterioplankton abundance and viability and their relationship with phosphorus across the Mediterranean Sea, Aquat. Microb. Ecol., 60, 175-191, doi:10.3354/ame01421, 2010.

Lasternas, S., Piedeleu, M., Sangrà, P., Duarte, C. M., and Agustí, S.: Forcing of dissolved organic carbon release by phytoplankton by anticyclonic mesoscale eddies in the subtropical NE Atlantic Ocean, Biogeosciences, 10, 2129-2143, doi:10.5194/bg10-2129-2013, 2013

Llabrés, M. and Agustí, S.: Picophytoplankton cell death induced by UV radiation: evidence for Oceanic Atlantic communities, Limnol. Oceanogr., 51, 21-29, 2006.

Llabrés, M., Agustí, S., Alonso-Laíta, P., and Herndl, G. J.: Synechococcus and Prochlorococcus cell death induced by UV radiation and the penetration of lethal UVR in the Mediterranean Sea, Mar. Ecol.-Progr. Ser., 399, 27-37, doi:10.3354/meps08332, 2010.

Marbá, N., Duarte, C. M., and Agustí, S.: Allometric scaling of plant mortality rate, P. Natl. Acad. Sci. USA, 104, 15777-15780, 2007.
Marie, D., Simon, N., and Vaulot, D.: Phytoplankton cell counting by flow cytometry, in: Algal Culturing Techniques, edited by: Andersen, R. A., Academic Press, San Diego, 253-267, 2005.

Moore, L. R., Post, A. F., Rocap, G., and Chisholm, S. W.: Utilisation of different nitrogen sources by marine cyanobacteria Prochlorococcus and Synechococcus, Limnol. Oceanogr., 47, 989-996, 2002.

Morán, X. A. G. and Calvo-Diaz, A.: Single-cell vs. bulk activity properties of coastal bacterioplankton over an annual cycle in a temperate ecosystem, FEMS Microbiol. Ecol., 67, 43-56, doi:10.1111/j.1574-6941.2008.00601.x, 2009.

Morán, X. A. G and Estrada, M.: Phytoplanktonic DOC and POC production in the Bransfield and Gerlache Straits as derived from kinetic experiments of ${ }^{14} \mathrm{C}$ incorporation, Deep-Sea Res. Pt. II, 49, 769-786, 2002.

Morán, X. A. G., Gasol, J. M., Pedrós-Alió, C., and Estrada, M.: Dissolved and particulate primary production and bacterial production in offshore Antarctic waters during austral summer: coupled or uncoupled?, Mar. Ecol.-Prog. Ser., 222, 25-39, 2001.

Morán, X. A. G., Estrada, M., Gasol, J. M., and Pedrós-Alió, C.: Dissolved primary production and the strength of phytoplankton - bacterioplankton coupling in contrasting marine regions, Microb. Ecol., 44, 217-223, doi:10.1007/s00248-002-1026-z, 2002a.

Morán, X. A. G., Gasol, J. M., Pedrós-Alió, C., and Estrada, M.: Partitioning of phytoplanktonic organic carbon production and bacterial production along a coastal-offshore gradient in the NE Atlantic during different hydrographic regimes, Aquat. Microb. Ecol., 29, 239-252, doi:10.3354/ame029239, 2002b.

Mühling, M., Fuller, N. J., Millard, A., Somerfield, P. J., Marie, D., Wilson, W. H., Scanlan, D. J., Post, A. F., Joint, I., and Mann, N. H.: Genetic diversity of marine Synechococcus and co-occurring cyanophage communities: evidence for viral control of phytoplankton, Environ. Microbiol., 7, 499-508, doi:10.1111/j.1462-2920.2004.00713.x, 2005.

Myklestad, S.: Production of carbohydrates by marine planktonic diatoms. II. Influence of the ratio in the growth medium on the assimilation ratio, growth rate, and production of cellular and extracellular carbohydrates by Chaetoceros affinis var. willei (Gran) Hustedt and Skeletonema costatum (Grev.) Cleve, J. Exp. Mar. Biol. Ecol., 29, 161-179, doi:10.1016/0022-0981(77)90046-6, 1977.

Nagata, T.: Production mechanisms of dissolved organic matter, in: Microbial Ecology of the Oceans, edited by: Kirchman, D., Wiley, New York, 121-151, 2000.

Nelson, C. E. and Carlson, C. A.: Tracking differential incorporation of dissolved organic carbon types among diverse lineages of Sargasso Sea bacterioplankton, Environ. Microb., 14, 1500-1516, 2012.

Norrman, B., Zweifel, U. L., Hopkinson, C. S., and Fry, B.: Production and utilization of dissolved organic carbon during an experimental diatom bloom, Limnol. Oceanogr., 40, 898-907, 1995.

Obernosterer, I. and Herndl, G. J.: Phytoplankton extracellular release and bacterial growth: dependence on the inorganic N : P ratio, Mar. Ecol.-Prog. Ser., 116, 247-257, 1995.

Parsons, T. R., Maita, Y., and Lalli, C. M.: A Manual of Chemical and Biological Methods for Seawater Analysis, Pergamon Press, Oxford, 1984. 
Pelegrí, J. L., Arístegui, J., Cana, L., González-Dávila, M., Hernández-Guerra, A., Hernández-León, S., Marrero-Díaz, A., Montero, M. F., Sangrá, P., and Santana-Casiano, M.: Coupling between the open ocean and the coastal upwelling region off Northwest Africa: water recirculation and offshore pumping of organic matter, J. Marine Syst., 54, 3-37, 2005.

Sarmento, H., Romera-Castillo, C., Lindh, M., Pinhassi, J., Sala, M., Gasol, J. M., Marrasé, C. and Taylor, G. T.: Phytoplankton species-specific release of dissolved free amino acids and their selective consumption by bacteria, Limnol. Oceanogr., 58, 1123-1135, 2013.

Shapiro, H. M.: Flow cytometry of bacterial membrane potential and permeability, in: New Antibiotic Targets, Methods in Molecular Medicine, edited by: Champney, W. S., 142, 175-186, doi:10.1007/978-1-59745-246-5_14 2008.

Sharp, J. H.: Excretion of organic matter by marine phytoplankton: do healthy cells do it?, Limnol. Oceanogr., 22, 381-399, 1977.

Sherr, E. B. and Sherr, B. F.: Role of microbes in pelagic food webs: a revised concept, Limnol. Oceanogr., 33, 1225-1227, 1988.

Sherr, E. B. and Sherr, B. F.: Bacterivory and herbivory: key roles of phagotrophic protists in pelagic food webs, Microb. Ecol., 28, 223-235, doi:10.1007/BF00166812, 1994.

Siegel, S. and Castellan, N. J.: Non-parametric Statistics for the Behavioural Sciences, McGraw Hill Company, New York, 1988.

Smith, E. M. and del Giorgio, P. A.: Low fractions of active bacteria in natural aquatic communities?, Aquat. Microb. Ecol., 31, 203-208, 2003.
Steemann-Nielsen, E. J.: The use of radioactive carbon $\left({ }^{14} \mathrm{C}\right)$ for measuring organic production in the sea, J. Cons. Perm. Int. Explor. Mer., 18, 117-140, 1952.

Teira, E., Pazo, M. J., Serret, P., and Fernandez, E.: Dissolved organic carbon production by microbial populations in the Atlantic Ocean, Limnol. Oceanogr., 46, 1370-1377, 2001.

Teira, E., Paz, M. J., Quevedo, M., Fuentes, M. V., Niell, F. X., and Fernández, E.: Rates of dissolved organic carbon production and bacterial activity in the Eastern North Atlantic Subtropical Gyre during summer, Mar. Ecol.-Prog. Ser., 249, 53-67, doi:10.3354/meps249053, 2003.

Veldhuis, M. J. W., Kraaij, G. W., and Timmermans, K. R.: Cell death in phytoplankton: correlation between changes in membrane permeability, photosynthetic activity, pigmentation and growth, Eur. J. Phycol., 36, 1-13, 2001.

Williams, P. J. le B.: Incorporation of microheterotrophic processes into the classical paradigm of the plankton food web, in: Lower Organisms and their Role in the Food Web: Proceedings of the 15th European Marine Biology Symposium, Kiel, Damp 2000, Federal Republic of Germany, 29 September-3 October 1980, edited by: Rheinheimer, G., Flügel, H., Lenz, J., Zeitzschel, B., Kieler Meeresforschungen. Sonderheft, 5, 1-28, 1981.

Zetsch, E. M. and Meysman, F. J. R.: Dead or alive? Viability assessment of micro- and mesoplankton, J. Plankton Res., 34 493-509, 2012. 